\title{
POTENSI DESA WISATA SABUNG AYAM NON JUDI DI KELURAHAN NGLEGOK, KEC. NGLEGOK, KAB. BLITAR (Strategi Konstruktif Mengatasi Judi Sabung Ayam Berbasis Wisata)
}

\author{
Sudirman, Didik Sukriono, Rusdianto Umar \\ sudirman.fis@um.ac.id, \\ Jurusan Hukum dan Kewarganegaraan, Fakultas IImu Sosial, Universitas Negeri Malang \\ Diterima 23 September 2019, dipublikasikan 31 Oktober 2019
}

\begin{abstract}
Abstrak
Sabung ayam di Kelurahan Nglegok, Kec. Nglegok, Kab. Blitar sudah menjadi tradisi yang melekat dalam kehidupan keseharian masyarakat, sehingga sulit untuk dicegah melalui cara-cara yang tidak mengakomodir tradisi tersebut. Pandangan negara terhadap budaya sabung ayam disamakan dengan perjudian, sehingga masyarakat yang melakukan sabung ayam sering ditangkap oleh aparat kepolisian. Penanggulangan sabung ayam melalui cara represif dengan sanksi pidana dan penggrebekan tidak akan menyelesaikan masalah dan justru akan melahirkan masalah-masalah baru dalam kehidupan masyarakat. Oleh karena itu perlu solusi yang dapat menyelesaikan masalah sabung ayam, namun tidak mencabut akar tradisi sabung ayam itu sendiri. Artinya masyarakat tetap dapat menyalurkan tradisi sabung ayam tanpa ada unsur pidana dalam tradisi yang dilakukan. Solusi yang dilakukan adalah pengembangan desa wisata sabung ayam non judi di Kelurahan Nglegok, Kec. Nglegok, Kab. Blitar. Metode yang digunakan adalah pemberdayaan masyarakat. Hasil dari pengembangan desa wisata sabung ayam non judi di Kelurahan Nglegok, Kec. Nglegok, Kab. Blitar dapat mengalihkan kebiasaan masyarakat judi sabung ayam menjadi sabung ayam non judi dalam bentuk kontes, meningkatkan ekonomi peternak ayam aduan, dan meningkatkan ekonomi masyarakat sekita tempat wisata sabung ayam non judi.
\end{abstract}

Kata Kunci: Desa Wisata, Sabung Ayam, Non Judi, Kelurahan Nglegok.

\section{PENDAHULUAN}

Kelurahan Nglegok adalah salah satu kelurahan yang ada di Kabupaten Blitar yang menyimpan potensi unik yaitu budaya sabung ayam. Secara kasat mata, potensi ini cenderung bernuasa negatif, karena sabung ayam identik dengan aktifitas ilegal yaitu judi sabung ayam. Stigmatisasi sabung ayam sebagai budaya terlarang terjustifikasi oleh ketentuan pidana perjudian sabung ayam. Pandangan satu arah terhadap sabung ayam, menenggelamkan potensi yang tersimpan di dalamnya. Padahal sabung ayam menyimpan potensi yang dapat dikembangkan untuk pemberdayaan masyarakat, seperti potensi peternakan dan wisata.

Kelurahan Ngelegok masuk dalam Kecamatan Ngelegok, Kabupaten Blitar, Propinsi Jawa Timur, yang penduduknya mayorits bekerja sebagai petani. Desa-desa yang membatasi Kelurahan Nglegok anatara lain: Sebelah Utara: Desa Penataran, Sebelah Selatan: Desa Jiwut, Sebelah Barat: Desa Kemloko, Sebelah Timur: Desa Modangan. Kelurahan Nglegok dapat ditempuh dengan semua kendaraan baik kendaraan bernotor maupun tidak karena kondisi jalannya ada yang sudah diaspal baik. Penduduk yang tidak memiliki kendaraan pribadi biasanya memanfaatkan kendaraan umum yang disana bisa disebut kol dan ojek. Kelurahan Nglegok tersedia alat angkutan umum tiap jam, tiap hari, dan tiap minggu selalu ada serta pangkalan ojek yang setiap hari bisa dimanfaatkan (Prayogo 2005).

Luas wilayah Kelurahan Nglegok 103,208,91 Ha, dengan rincian pemukiman umum 102,656 $\mathrm{Ha}$, luas pertanian sawah yaitu sawah pengairan teknis atau irigasi $52,476 \mathrm{Ha}$, luas ladang atau tegalan $3 \mathrm{Ha}$. Lahan Nglegok hanya berupa dataran mencapai luas 344,216 Ha. Tidak terdapat perbukitan atau pegunungan di Kelurahan Nglegok. Kelurahan Nglegok masih banyak terdapat pertanian sawah yang menempati urutan terluas setelah ladang/ tegalan (usaha tani tanah kering 
tidak terpisah dari halaman rumah, di halaman tersebut ditanami dengan tanaman yang berumur pendek seperti palawija dan beberpa tanarnan berumur seperti kelapa, pepaya, mangga dII). Jadi hampir $80 \%$ tanah Kelurahan Nglegok berupa sawah pengairan teknis atau irigasi (sistem pengairan yang dilengkapi dengan jaringan induk, jaringan sekunder dan tresier dimana pemanfaatannya dapat diukur untuk sepanjang tahun sehingga memungkinkan sistem internsifikasi usaha tani sawah) dan belum ada sawah pengairan setengah teknis (sistem pengairan yang berasal dari saluran irigasi jaringan waduk/ bendungan untuk jaringan sekunder dan tersier belum tersedia), sawah tadah hujan (pengairan sawah yang sumber pengairannya dari air hujan dan sumber air tidak tetap lainnya/mata air yang mengeluarkan air pada musim hujan dan kering pada musim kemarau), sawah pasang surut (pertanian sawah yang terletak sepanjang pantai dimana pengairannya secara langsung atau tidak langsung oleh gerakan pasang surut air laut) (Prayogo 2005).

Pola pemukiman pada masyarakat Kelurahan Nglegok adalah berupa perkampungan yang berbentuk memanjang dengan mengikuti arah jalan poros yang melintasi wilayah tersebut. Rumahrumah masyarakat Kelurahan Nglegok pada umumnya bergerombol dengan halaman yang sempit dan menghadap ke jalan. Kondisi dari bangunan ada yang sudah permanen dengan dinding tembok berlantaikan ubin atau semen namun tidak sedikit yang masih berdinding anyaman bambu mekipun atapnya sudah diganti genting. Kelurahan Nglegok sebagian besar penduduknya adalah masyarakat petani. Masyarakat Kelurahan Nglegok sebagian besar bermata pencaharian sebagai petani, karena areal lahan Kelurahan Nglegok sebagian besar juga areal persawahan. Penduduk Kelurahan Nglegok berjumlah 4.388 jiwa dengan rincian laki-laki 2.080 jiwa sedang perempuan 2.308 jiwa. Jumlah penduduk yang berjenis kelamin perempuan dengan laki-laki hampir seimbang terbukti hanya selisih $5,5 \%$ dari jumlah penduduk seluruhnya. Kelurahan Nglegok di lihat dari pendidikan sudah banyak yang mengenyam pendidikan walaupun mayoritas masih setingkat SD dan SMP. Lulusan SD mencapai $79 \%$ sedangkan yang lulus SMP $12 \%$ perbandingan antara penduduk yang mengenyam pendidikan dengan yang tidak mengenyam pendidikan adalah 2:1 Jadi ada sekitar 1435 penduduk atau $33 \%$ penduduk yang tidak mengenyam pendidikan (Prayogo 2005).

Seni dan budaya daerah Nglegok mempunyai potensi yang cukup besar untuk terus dikembangkan, berhubungan dengan masyarakatnya yang kreatif dan dinamis. Jenis seni dan budaya yang ada di Kelurahan Nglegok adalah seni jaranan, seni tiban, dan wayang kulit, sabung ayam. Seni dan permainan yang setiap hari selalu ada dan digemari oleh masyarakat kelurahan Nglegok adalah sabung ayam. Sabung ayam mempunyai tempat tersendiri di hati masyarakat dan menyimpan potensi untuk dikembangkan menjadi potensi ekonomi bagi masyarakat sekitar.

Bagi masyarakat Kelurahan Nglegok, sabung ayam adalah sebuah budaya. Hal tersebut sejalan dengan pandangan Geertz (2000) yang menyatakan sabung ayam merupakan tradisi yang memiliki makna kultural. Pecinta sabung ayam telah mengembangkan rasionalisasi yang mereka gunakan di antara mereka sendiri dan menjadi sebuah budaya (Ragone 2016), bahkan beberapa di antaranya terang-terangan didasari oleh rasionalisasi mistis (Hawley 1993). Ayam dipandang sebagai lambang keberanian dan perlawanan dalam menghadapi peluang yang tidak dapat diatasi (Hawley 1993). Terdapat pandangan juga bahwa sabung ayam jantan sebagai potensi pertenakan, olahraga dan mempererat hubungan sosial (Powell Jr 1993). Dalam sabung ayam terdapat suasana kekeluargaan dari pertarungan sabung ayam (Forsyth 1996). Jadi sabung ayam bagi masyarakat Kelurahan Nglegok menjadi tradisi yang melekat dalam kehidupan sehari-hari.

Sabung Ayam di Kelurahan Nglegok ini susah sekali untuk dihilangkan dari masyarakat desa karena sudah mendarah daging dalam kehidupan sebagian masyarakat Kelurahan Nglegok walaupun sudah di larang keras oleh pihak yamg berwajib, tetapi pada kenyataanya masih tetap ada dan berlangsung, walaupun kegiatan sabung ayam di lakukan secara sembunyi-sembunyi tetapi kegiatanya tetap ada setiap hari. Ada dua jenis permainan sabung ayam yang ada di desa Nglegolk pengelompokan ini berdasarka kelas ekonomi di Kelurahan Nglegok dan besar taruhanya. Sabung ayam bentuk pertama, uang taruhanya hanya sekitar $\mathrm{Rp} 25.000$ - Rp 50.000. Sabung ayam bentuk ke dua, jumlah taruhan sebesar ratusan ribuan. Jika bertaruh sebesar Rp. 500.000, maka ia mendapatkan dua kali lipat dan di kurangi biaya retribusi. 
Tradisi sabung ayam yang ada unsur judinya tersebut yang kemudian oleh negara sabung ayam dianggap sebagai judi. Sabung ayam dipandang sebagai perbuatan ilegal dan melanggar hukum dengan mengkatagorikan sama dengan perbuatan judi. Hal ini didasarkan pada ketentuan pasal 303 KUHP, pasal 542 KUHP, sebutan pasal 542 KUHP, dan pasal 303 bis KUHP. Pandangan negara ini sejalan dengan pandangan Lindquist (2007) yang menyatakan sabung ayam justru sebagai perbuatan ilegal yang bermotif ekonomi. Pandangan negara ini yang menjadikan sabung ayam di Kelurahan Nglegok banyak dilakukan penggrebekan oleh aparat penegak hukum.

Berdasarkan pemikiran ini, perlu ada terobosan untuk memfasilitasi budaya masyarakat, namun tidak bertentangan dengan aturan hukum. Budaya sabung ayam yang berkembang di masyarakat Kelurahan Nglegok harus mampu dikemas sedemikian rupa sehingga tradisi yang melekat dalam masyarakat tidak bertentangan dengan hukum dan masyarakat tidak berhadapan dengan aparat penegak hukum. Solusi yang dapat dikemukakan terhadap masalah ini adalah pengembangan budaya sabung ayam berbasis wisata. Dengan model pengembangan budaya sabung ayam berbasis wisata, maka budaya masyarakat tetap akan lestari namun tidak bertentangan dengan hukum, dan bahkan dapat memberikan pemasukan bagi kas pemerintahan desa. Berdasarkan pertimbangan tersebut, judul pengabdian masyarakat ini adalah "Penegmbangan Desa Wisata Sabung Ayam Non Judi di Kelurahan Nglegok, Kec. Nglegok, Kab. Blitar (Strategi Kontruktif Mengatasi Judi Sabung Ayam Berbasis Wisata)"

Berdasarkan analisis situasi di atas, permasyalahan dalam pengamdian masyarakat ini adalah: (1) terdapat budaya sabung ayam di Kelurahan Nglegok, Kec. Nglegok, Kab. Blitar; (2) budaya sabung ayam di Kelurahan Nglegok, Kec. Nglegok, Kab. Blitar dianggap perjudian sehingga dihadapkan pada sanksi pidana KUHP; (3) perlu ada solusi mengemas budaya sabung ayam supaya tidak bertentangan dengan hokum; (4) perlu pengembangan desa wisata sabung ayam non judi di Kelurahan Nglegok, Kec. Nglegok, Kab. Blitar.

Manfaat program ini adalah sebagai berikut: (1) bagi masyarakat Kelurahan Nglegok, Kec. Nglegok, Kab. Blitar, pengabdian masyarakat ini akan melestarikan budaya sabung ayam tanpa bertentangan dengan hokum; (2) bagi pemerintahan Kelurahan Nglegok, Kec. Nglegok, Kab. Blitar, program ini akan mendatangkan potensi pemasukan kas desa; (3) Bagi penegak hukum, program ini akan mengurangi tingkat perjudian sabung ayam di masyarakat; (4) Bagi universitas, program ini akan menjadi model pemberdayaan masyarakat berbasis wisata dan budaya masyarakat.

\section{METODE}

Pendekatan yang dapat digunakan untuk menyelesaikan masalah sabung ayam, namun tidak mencabut akar tradisi sabung ayam adalah pengembangan desa wisata sabung ayam non judi di Kelurahan Nglegok, Kec. Nglegok, Kab. Blitar. Pengembangan desa wisata sabung ayam non judi di Kelurahan Nglegok, Kec. Nglegok, Kab. Blitar ini dikemas dalam bentuk pemberdayaan masyarakat. Masyarakat Kelurahan Nglegok, Kec. Nglegok, Kab. Blitar secara mandiri mengembangkan dengan pendampingan tim pengabdian Universitas Negeri Malang. Pioner dalam pengembangan desa wisata ini adalah organisasi karang taruna Swana Ghana, sebuah karang taruna yang aktif di Kelurahan Nglegok, Kec. Nglegok, Kab. Blitar, namun belum bergerak dalam bidang wisata. Karang taruna Swana Ghana di Kelurahan Nglegok, Kec. Nglegok, Kab. Blitar selama ini masih terbatas mengelola parkir dan sampah. Disamping pelibatan karang taruna, pengembangan desa wisata ini tentunya tidak lepas dari peran serta pemerintahan Kelurahan Nglegok, Kec. Nglegok, Kab. Blitar. Pemerintahan desa adalah pemegang otoritas, sedangkan karang taruna adalah pelaksananya. Meskipun demikian mitra pengabdian ini lebih terfokus pada Karang Taruna Swana Ghana demi pertimbangan efektifitas dan akseleritas. Pengabdian ini juga akan berhubungan dengan pihak kepolisian dalam hal ini Polsek Nglegok dan Polres Blitar berkaitan dengan perijinan. Tahap selanjutnya juga berkerjasama dengan pemerintah kabupaten Blitar.

Langkah pengembangan desa wisata sabung ayam non judi di Kelurahan Nglegok, Kec. Nglegok, Kab. Blitar dilakukan dengan langkah sebagai berikut: (1) observasi potensi pendukung pengembangan desa wisata; (2) pembekalan dan perencanaan desa wisata sabung ayam; dan (3) pendampingan pembuatan even desa wisata. 


\section{HASIL DAN PEMBAHASAN}

Pokok permasalahan yang terdapat di Kelurahan Nglegok, Kec. Nglegok, Kab. Blitar adalah terdapat budaya sabung ayam yang digandrungi oleh masyarakat, terutama golongan laki-laki. Sabung ayam sudah menjadi tradisi yang melekat dalam kehidupan keseharian masyarakat Kelurahan Nglegok, Kec. Nglegok, Kab. Blitar, sehingga sulit untuk dicegah melalui cara-cara yang tidak mengakomodir tradisi tersebut. Pandangan negara terhadap budaya sabung ayam disamakan dengan perjudian, sehingga masyarakat yang melakukan sabung ayam sering ditangkap oleh aparat kepolisian dalam sebuah operasi, dan tidak jarang ada yang masuk penjara. Meskipun demikian masyarakan Kelurahan Nglegok, Kec. Nglegok, Kab. Blitar tetap melakukan tradisi sabung ayam walaupun harus main kejar-kejaran dengan aparat kepolisian.

Penggunaan cara represif ala penggrebekan seperti yang dilakukan oleh aparat kepolisian tidak akan meyelesaikan masalah yang ada dalam kehidupan masyarakat. Sabung ayam bagi masyarakat Kelurahan Nglegok, Kec. Nglegok, Kab. Blitar sudah menjadi tradisi, sehingga dari tradisi tersebut melahirkan sebuah konsep hukum yaitu budaya hukum. Budaya hukum adalah gagasan, nilai, sikap, dan pendapat orang-orang di beberapa masyarakat, berkaitan dengan hukum dan sistem hukum (Friedman 1994). Menurut Febbrajo (2018) Budaya hukum adalah tentang bagaimana masyarakat memandang hukum dan bagaimana hukum memandang masyarakat. Mengacu pada ide, harapan dan sikap terhadap hukum dan lembaga hukum. Masing-masing elemen ini dapat ditempatkan pada berbagai tingkatan abstraksi, mulai dari ide dan nilai yang lebih abstrak hingga ekspektasi sikap individu yang konkret (Febbrajo 2018). Hal sama disampaikan oleh Toharia (2011) bahwa budaya hukum pada dasarnya terdiri dari nilai-nilai, sikap, dan pendapat yang terkait dengan sistem hukum. Budaya hukum merupakan variabel yang sangat penting untuk mendapatkan pemahaman yang lebih baik tentang bagaimana sistem hukum beroperasi. Budaya hukum sabung ayam Kelurahan Nglegok, Kec. Nglegok, Kab. Blitar adalah bukan pelanggaran hukum. Kesadaran bahwa sabung ayam bukan pelanggaran hukum dalam masyarakat Kelurahan Nglegok, Kec. Nglegok, Kab. Blitar, bertentangan 180 derajat dengan pemahaman negara terhadap sabung ayam yang dianggap pebuatan melanggar hukum. Perbedaan pemahaman demikian layaknya minyak dan air yang tidak akan pernah bertemu.

Pertentangan tradisi sabung ayam yang dipahami oleh masyarakat Kelurahan Nglegok, Kec. Nglegok, Kab. Blitar dengan pemahaman negara telah menjadi fenomena yang umum di kalangan masyarakat Jawa dan Bali. Pendapat ini didasarkan pada penelitian Geertz yang menyatakan bahwa orang Bali dan orang Jawa yang melakukan sabung ayam, meskipun dilakukan penggrebekan, menyita ayam, denda bagi beberapa orang, dan bahkan menjemur di bawah sinar matahari sebagai efek jera, namun pencinta ayam tidak peduli dan mengabaikannya bahkan mengulanginya secara diam-diam tanpa menarik perhatian hukum (Geertz 2000). Pendapat yang didasarkan pada penelitian ilmiah ini menjadi dasar bahwa penanggulangan sabung ayam melalui cara represif dengan sanksi pidana dan penggrebekan tidak akan menyelesaikan masalah dan justru akan melahirkan masalahmasalah baru dalam kehidupan masyarakat, semisal terjadi kecelakaan orang yang melakukan sabung ayam yang berakibat meninggal dunia karena menghindari pengejaran aparat kepolisian. Oleh karena itu tugas dari negara dalam hal ini adalah aparat penegak hukum adalah mengatur sabung ayam sehingga tidak menjadi judi, bukan justru melarangnya. Apabila negara melarangnya, maka akan ada penolakan dari masyarakat pecinta sabung ayam.

Salah satu bentuk pengaturan sabung ayam, sehingga terbebas dari unsur perjudian adalah pengembangan desa wisata sabung ayam. Sabung ayam diatur dan dikemas sebagai kontes, bukan sebagai sarana perjudian. Orang datang bukan untuk berjudi tapi untuk memperoleh hiburan, menyalurkan hobi, dan bertransaksi (jual beli) ayam. Langkah pengembangan desa wisata sabung ayam non judi dilakukan dengan langkah berikut:

\section{Observasi Pendukung Pengembangan Desa Wisata}

Observasi pendukung pengembangan desa wisata adalah tahap awal dari pelaksanaan pengembangan desa wisata sabung ayam non judi. Observasi yang dimaksud adalah pengumpulan data awal untuk mendukung pelaksanaan pembuatan desa wisata sabung ayam non judi. Observasi 
pertama yang dilakukan adalah kesiapan dari pemerintahan kelurahan Nglegok. observasi dilakukan dengan mengadakan pertemuan langsung dan sekaligus pengurusan perijinan di kantor kelurahan Nglegok dan ditemui langsung oleh Lurah Nglegok. Tanggapan dari Lurah Nglegok dan pemerintahan kelurahan Nglegok cukup positif dan memberikan dukungan kepada tim pengembang desa wisata untuk mengembangkan desa wisata sabung ayam non judi. Lurah Nglegok mengemukakan bahwa hampir $90 \%$ kepala keluarga di kelurahan Nglegok memiliki pekerjaan sampingan sebagai peternak ayam aduan. Apabila kelurahan Nglegok dijadikan sebagai desa yang khusus menawarkan ayam aduan baik dalam bentuk kontes ataupun peternakan ayam aduan sangat cocok. Lurah Nglegok juga mengungkapkan bahwa pemerintah kelurahan Nglegok akan mengakomodir setiap potensi yang ada di kelurahan Nglegok, termasuk budaya sabung ayam, dengan syarat cara-cara mengakomodir budaya tersebut tidak bertentangan dengan aturan hukum. Apabila sabung ayam dapat dipisahkan dengan unsur judi yang mengiringinya, maka pemerintah kelurahan Nglegok mendukung pengembangan potensi sabung ayam yang ada di kelurahan Nglegok.

Bagi pemerintah kelurahan Nglegok, pendekatan baru yang ditawarkan oleh tim pengembang wisata, yaitu mengembangkan potensi sabung ayam yang terlepas dari unsur perjudian adalah hal yang baru. Tidak perna ada pihak luar yang menawarkan perspektif baru dalam melihat sabung ayam. Pandangan yang ada selama ini cenderung sabung ayam diidentikkan dengan perjudian. Apabila perpektif baru ini, yaitu mengembangkan potensi desa wisata sabung ayam non judi dapat diterapkan, maka akan dapat mengatasi permasalahan perjuadian sabung ayam di kelurahan Nglegok, dan dapat meningkatkan potensi perekonomian masyarakat.

observasi selanjutnya dilakukan dengan melakukan pertemuan ke tokah-tokoh masyarakat yang ada di Kelurahan Nglegok. Tokoh yang menjadi sasaran observasi adalah tokoh yang memiliki perternakan ayam aduan dan pecinta sabung ayam. Dari observasi di masyarakat diketahui bahwa selama ini masyarakat kelurahan Nglegok memang menggeluti sabung ayam dan bahkan sudah ada yang menggeluti sabung ayam non judi. Dari pengamatan setiap rumah yang ada di kelurahan Nglegok terlihat jelas klaim Lurah Nglegok yang menyatakan bahwa hampir 90\% kepala keluarga memiliki pekerjaan sampingan sebagai peternak ayam aduan, karena disetiap rumah yang ada di kelurahan Nglegok terpampang ayam aduan yang dikurung dan diumbar di depan/samping rumah mereka.

Dari observasi ke tokoh masyarakat, diketahui bahwa sabung ayam sudah menjadi rutinitas keseharian masyarakat kelurahan Nglegok. Diakui sebagian besar masyarakat kelurahan Nglegok masih bermain sabung ayam yang ada unsur judinya. Akan tetapi, terdapat pula masyarakat yang sudah merintis sabung ayam dalam bentuk latihan bersama (latber) yang di dalamnya tidak ada unsur judinya, sebatas sparing ayam dengan tujuan akhir jual beli ayam. Ayam yang terpantau teknik dan pukulannya baik, diperjual belikan antar peserta latber. Berdasarkan pemaparan Bambang, salah satu tokoh terkemuka dalam perayaman di kelurahan Nglegok, apabila sabung ayam di arahkan menjadi wisata desa yang terbebas dari unsur perjudian, justru akan mendatangkan keuntungan bagi masyarakat kelurahan Nglegok. Pertama, kebiasaan masyarakat akan teralihkan dari sabung ayam yang ada judinya menjadi sabung ayam non judi. Hal ini selain akan melahirkan ketertiban dalam masyarakat, juga akan menghindarkan masyarakat dari tindakan represif aparat penegak hukum seperti penggrebekan, penahanan, dan denda yang memberatkan masyarakat. Kedua, pembuatan desa wisata sabung ayam akan mendatangkan manfaat ekonomi bagi peternak sabung ayam dan masyarakat sekitar. Dengan demikian beliau mendukung rencana pengembangan desa wisata sabung ayam non judi di kelurahan Nglegok, bahkan bersedia menyediakan tempat apabila akan dilakukan even kontes sabung ayam.

Observasi yang dilakukan didampingi oleh ketua karang taruna kelurahan Nglegok, yaitu Danil Sugeng Prayogo yang sekaligus menjadi patner dalam pengembangan desa wisata sabung ayam. Dari hasil observasi diperoleh kesimpulan bahwa pemerintah kelurahan Nglegok dan masyarakat Nglegok menyambut baik rencana pengembangan desa wisata sabung ayam. Dengan demikian, pengembangan potensi desa wisata sabung ayam non judi dapat dan layak dilaksanakan. 


\section{Pembekalan dan Perencanaan Desa Wisata Sabung Ayam}

Tahap pembekalan dan perencanaan adalah tahap kedua dalam pengembangan desa wisata sabung ayam non judi. Tahap ini dilaksanakan untuk membekali pengetahuan masyarakat Kelurahan Nglegok, Kec. Nglegok, Kab. Blitar tentang pengembangan desa wisata. Harapannya dari pembekalan ini masyarakat memiliki wawasan dan pemahaman awal tentang pengembangan desa wisata. Pembekalan dilakukan dengan metode dialog interaktif dengan mendatangkan pemateri dari Universitas Negeri Malang, Perkumpulan Pecinta Sabung Ayam Indonesia dan PT. Charoen Pokphand Indonesia Tbk. Pembekalan dilaksanakan di balai Kelurahan Nglegok, Kec. Nglegok, Kab. Blitar dan dihadiri oleh anggota Karang Taruna Swana Ghana, Perangkat Desa, dan Tokoh Masyarakat.

Pembekalan dan perencanaan desa wisata sabung ayam diawali dengan pemberian perspektif baru bagi masyarakat, yaitu paradigma bahwa sabung ayam bukan segalanya tentang perjudian. Masyarakat perlu diberikan wawasan tentang merubah mindseat bahwa segala sesuatu pasti mengandung unsur negatif dan positif termasuk juga sabung ayam. Sabung ayam dapat menjadi negatif apabila sabung ayam dijadikan sebagai sarana perjudian. Bahkan tidak hanya sabung ayam, apapun itu apabila memang diniatkan sebagai sarana perjudian akan menjadi sarana perjuadian, semisal sepakbola, kartu remi, dan lain-lain. Akan tatapi, disatu sisi, setiap hal juga akan mengandung potensi positif apabila diarahkan ke hal positif. Sepak bola menjadi olahraga, kartu remi menjadi olahraha bridge, demikian pula sabung ayam apabila diarahkan ke hal positif dapat menajdi potensi wisata kontes sabung ayam.

Dimisalkan dengan pisau, dapat bermakna positif apabila digunakan untuk memasak, namun dapat pula seseorang menggunakan pisau untuk membunuh orang lain. Artinya keberadaan pisau yang semula dimaksudkan untuk digunakan memasak, dapat dipergunakan untuk membunuh orang. Lantas, dengan adanya pembunuhan yang menggunakan pisau, tidak kemudian melarang keberadaan pisau, namun masyarakat diedukasi untuk menggunakan pisau untuk memasak bukan untuk membunuh. Demikian pula dengan sabung ayam, digunakan masyarakat untuk sarana perjudian, tidak lantas melarang sabung ayam, namun masyarakat diedukasi agar sabung ayam digunakan sebagai sarana menarik minat wisatawan untuk menikmati kontes sabung ayam dalam desa wisata sabung ayam non judi. Pembekalan dan perencanaan desa wisata sabung ayam non judi harus memuat pemahaman "Pentingnya Pengembangan Desa Wisata dan Merubah Paradigma Negatif Sabung Ayam Paradigma".

Pengetahuan selanjutnya yang harus dipahami oleh masyarakat adalah perubahan aturan antara sabung ayam judi dengan sabung ayam kontes (non judi). Dalam sabung ayam judi, kemenangan ditentukan dengan keok tidaknya ayam, gandeng ayam berdasarkan berat, tinggi dan tulangan ayam, serta cenderung lepas jalu. Sabung ayam judi di kalangan pecinta sabung ayam dikenal dengan istilah Pro. Dalam kontes sabung ayam ketentuannya berbeda, kemenangan ditentukan berdasarkan poin. Gandeng ayam berdasarkan berat badan dan tutup jalu, sehingga menghindarkan ayam dari cedera fatal. Perubahan peraturan sabung ayam ini secara tidak langsung juga akan merubah maindset masyarakat, yang awalnya ayam hanya sebagai sarana judi yang tidak memikirkan sisi-sisi perlindungan terhadap hewan, dengan melepas jalu ayam dalam pertandingan, menjadi tutup jalu yang lebih peduli terhadap perlindungan akan keselamatan ayam.

Pemahaman selanjutnya yang perlu dipahami masyarakat adalah metode berternak ayam aduan. Pengembangan desa wisata sabung ayam non judi akan mengedepankan aspek jual beli ayam aduan. Artinya masyarakat akan memasarkan kepada wisatawan yang datang melihat sabung ayam. Hasil perternakan masyarakat kelurahan Nglegok harus berkualitas baik. Oleh karena itu, pembekalan metode berternak ayam aduan menjadi hal yang sangat penting. Melalui pembekalan ini masyarakat akan memiliki pengetahuan dalam memelihara, merawat, dan melatih ayam aduan yang berkualitas baik.

\begin{tabular}{lll}
\hline \multicolumn{1}{c}{ Topik } & \multicolumn{1}{c}{ Nara Sumber } & \multicolumn{1}{c}{ Asal Instansi } \\
\hline Pentingnya Pengembangan & Dr. Didik Sukriono, S.H., & Universitas Negeri \\
Desa Wisata dan Merubah & M.Hum. & Malang \\
Paradigma Negatif Sabung & & \\
\hline
\end{tabular}




\begin{tabular}{lll}
\hline $\begin{array}{l}\text { Ayam Paradigma } \\
\text { Sistem Kontes Ayam Aduan }\end{array}$ & Hendra & $\begin{array}{l}\text { Perkumpulan Pencinta } \\
\text { Non Judi }\end{array}$ \\
$\begin{array}{ll}\text { Metode berternak Ayam } \\
\text { Aduan yang Baik }\end{array}$ & Teguh & PT. Charoen Pokphand \\
\hline
\end{tabular}

Tabel 1. Topik dan Narasumber Pembekalan dan Perencanaan Desa Wisata Sabung Ayam

Pelaksanaan pembekalan dan perencanaan desa wisata sabung ayam berjalan dengan baik. Semua elemen masyarakat yang diundang yang terdiri dari perangkat desa, pecinta sabung ayam, peternak ayam, karang taruna, dan tokoh masyarakat dapat hadir dan mengikuti acara yang diselenggarakan. Dalam acara ini segenap tokoh masyarakat kelurahan Nglegok juga melakukan musyawarah untuk menyepakati pelaksanaan event kontes sabung sebagai icon utama desa wisata yang hendak dikembangkan. Pelaksanaan event sabung ayam dilaksanakan dengan sistem kontes dengan mengadopsi aturan dari Perkumpulan Pecinta Ayam Indonesia (PPAl). Kegiatan didukung oleh sponsor PPAI dan PT. Charoen Pokphand Indonesia Tbk.

\section{Pendampingan Pembuatan Event Desa Wisata}

Pendampingan pembuatan event desa wisata adalah tahap ketiga dari pelaksanaan pengabdian. Tahapan ini dilakukan dengan pertimbangan bahwa desa wisata yang akan dikembangkan adalah desa wisata sabung ayam non judi. Dengan demikian desa wisata ini memerlukan icon event yang dapat menarik para pecinta sabung ayam untuk datang di kelurahan Nglegok untuk menyalurkan hobi dan kesenangan mereka. Event yang akan dilaksanakan sebagai ikon desa wisata adalah kontes sabung ayam non judi, yaitu sabung ayam yang dikemas dalam aturan kontes layaknya permainan tinju. Dalam kontes ini para pecinta sabung ayam dapat melihat aduan sabung ayam dan membeli ayam, sehingga peternak ayam yang ada di kelurahan Nglegok dapat menggunakan kesempatan ini untuk memasarkan hasil ternak mereka. Disamping itu, para pecinta ayam yang datang juga memerlukan makan dan minum, hal ini akan menggerakan usaha kecil dan menengah yang bergerak dalam usaha makanan dan minuman yang ada di kelurahan Nglegok.

Pelaksanaan pendampingan pembuatan event ini dalam skala yang besar meliputi cakupan antar kabupaten masih terkendala ijin dari kepolisian. Kondisi ini mencerminkan bahwa pihak kepolisian sebagai pelaksana hukum di Indonesia juga masih memiliki keraguan bahwa sabung ayam dapat terhindar dari unsur judi. Artinya pola pikir pihak kepolisian masih menggangap sabung ayam sebagai sarana perjudian. Oleh karena itu, perlu ada koordinasi yang jelas antara tim pengembangan desa wisata dengan pihak kepolisian. Koordinasi baik dengan pihak kepolisian untuk memastikan ijin pelaksanaan event kontes sabung ayam yang akan dilaksanakan tidak mendapatkan kendala.

Kendala perijinan dari pihak kepolisian disiasati dengan dilaksanakannya kontes sabung ayam dalam format latihan bersama (latber). Latber ini dilakukan secara rutin setiap malam minggu. Latber mengadopsi sistem permainan kontes sabung ayam, namun tidak dilakukan secara resmi hanya sebagai latihan rutin. Meskipun hanya dikemas dalam latihan bersama, kegiatan ini juga dapat mengundang masyarakat pecinta sabung ayam untuk datang menyaksikan dan turut serta dalam latber yang dilakukan. Masyarakat pecinta sabung ayam tidak hanya datang dari Kelurahan Nglegok, namun juga datang dari desa tetangga dan bahkan dari luar kecamatan Nglegok. Hal ini menandakan bahwa sabung ayam yang dikemas dalam konteks apapun dapat menarik masyarakat luar untuk datang menyaksikan. Artinya sabung ayam menyimpan daya tarik wisatawan, meskipun untuk sementara hanya wisatawan lokal, untuk datang ke kelurahan Nglegok.

Dari kegiatan latber yang dilakukan, masyarakat pecinta sabung ayam di kelurahan Nglegok dapat memasarkan ayam hasil ternaknya yang dinilai bagus oleh peserta yang datang di acara latber. Acara tersebut menjadi tempat mempromosikan hasil ternakan ayam masyarakat sekitar yang dinilai memiliki kualitas baik. Masyarakat sekitar juga dapat mengelola parkir dan usaha makanan di tempat latber dilaksanakan. Hal tersebut menandakan bahwa kegiatan latber dapat membawa dampak ekonomi bagi masyarakat. Apabila kegiatan latber dikembangkan dalam konteks yang lebih besar yaitu kontes sabung ayam yang tidak hanya bersifat lokal, dampak ekonomi yang dihasilkan juga 
akan semakin besar. Dari kegitan ini dapat menjadi data awal bahwa pengembangan desa wisata sabung ayam non judi dapat dioptimalkan sehingga berdampak positif bagi masyarakat yaitu disatu sisi dapat mengurangi perbuatan ilegal judi sabung ayam, dan di satu sisi dapat meningkatkan ekonomi masyarakat sekitar.

\section{KESIMPULAN}

Wisata sabung ayam non judi dapat mengalihkan kebiasaan masyarakat dari judi sabung ayam menjadi sabung ayam non judi. Hal ini dilakukan untuk menghindarkan kebiasaan masyarakat dari judi sabung ayam, namun tidak mencabut akar tradisi dan minat pecinta sabung ayam terhadap sabung ayam. Masyarakat tetap dapat melakukan sabung ayam, akan tetapi tidak melanggar hukum pidana perjudian. Dampak selanjutnya dari wisata sabung melahirkan ketertiban dalam masyarakat, juga menghindarkan masyarakat dari tindakan represif aparat penegak hukum seperti penggrebekan, penahanan, dan denda yang memberatkan masyarakat.

Desa wisata sabung ayam juga mendatangkan manfaat ekonomi bagi peternak sabung ayam. Selama ini peternak ayam aduan di kelurahan Nglegok kesulitan untuk memasarkan ayam aduan yang dihasilkan, sehingga desa wisata sabung ayam akan menjadi ajang bagi peternak ayam aduan untuk memasarkan dan menjual hasil ternakan yang dihasilkan. Disamping itu, masyarakat sekitar juga mendapatkan keuntungan ekonomi dengan mengelola parkir wisatawan dan usaha makanan dan minuman bagi wisatawan yang datang menyaksikan sabung ayam.

\section{DAFTAR PUSTAKA}

Febbrajo, Alberto. 2018. Law, Legal Culture and Society: Mirrored Identities of the Legal Order. Taylor \& Francis.

Forsyth, Craig J. 1996. "A PECKING DISORDER: Cockfighting in Louisiana." International Review of Modern Sociology 26(1): 15-25.

Friedman, Lawrence M. 1994. "Is There a Modern Legal Culture?" Ratio Juris 7(2): 117-31.

Geertz, Clifford. 2000. "Deep Play: Notes on the Balinese Cockfight." Dalam Culture and Politics, Palgrave Macmillan, New York, 175-201. https://link.springer.com/chapter/10.1007/978-1-349-62397-6_10 (Agustus 15, 2018).

Hawley, Fred. 1993. "The Moral and Conceptual Universe of Cockfighters: Symbolism and Rationalization." Society \&amp; Animals 1(2): 159-68.

Lindquist, John. 2007. "Deep Pockets: Notes on the Indonesian Cockfight in a Globalizing World." SPAFA Journal (Old series 1991-2013) 17(3). http://www.spafajournal.org/index.php/spafa1991journal/article/view/82 (Agustus 15, 2018).

Powell Jr, Richard E. 1993. "Sport, social relations and animal husbandry: early cockfighting in north America." The International Journal of the History of Sport 10(3): 361-81.

Prayogo, Danil Sugeng. 2005. Nilai Nilai Budaya Sabung Ayam di Desa Nglegok, Kec. Nglegok, Kab. Blitar. Malang: Skripsi Program Studi Pendidikan Pancasila dan Kewarganegaraan.

Ragone, Agnes. 2016. "Bayou Country Bloodsport: The Culture of Cockfighting in Southern Louisiana Jon Griffin Donlon. Jefferson: McFarland, 2014." The Journal of American Culture 39(1): 85-86.

Toharia, José Juan. 2011. "Exploring Legal Culture." Dalam Law, Society, and History, ed. Robert W. Gordon dan Morton J. Horwitz. Cambridge: Cambridge University Press, 90-100.

https://www.cambridge.org/core/product/identifier/CBO9780511921629A016/type/bo ok_part (Januari 8, 2019). 